\title{
Entrepreneurial Spirit Among University Students in Indonesia
}

\author{
Ratih Indriyani $^{1^{*}}$, Regina Cindy Darmawan ${ }^{1}$, and Ayoub Gougui ${ }^{2}$ \\ ${ }^{1}$ Department of Management, Faculty of Business and Economics, Petra Christian University, \\ J1. Siwalankerto 121-131, Surabaya 60236, Indonesia. \\ ${ }^{2}$ School of Business Management, College of Business, Universiti Utara Malaysia
}

\begin{abstract}
The current era of globalization is driving a lot of competition. Competition is increasing, but it is not balanced with available job openings and causes educated unemployment to increase. Educated unemployment is increasing and encouraging people to try professions to become entrepreneurs. Based on previous research, entrepreneurial creativity has an effect on entrepreneurial spirit and entrepreneurial mindset on entrepreneurial spirit. The entrepreneurial creativity has an effect on entrepreneurial spirit, on the other side entrepreneurial mindset has an effect on entrepreneurial spirit. Research conducted emphasizes the impact of entrepreneurial creativity and entrepreneurial mindset on entrepreneurial spirit among undergraduate students in Surabaya. This research takes data. This data is taken from a private university in surabaya with management study program A accreditation with a total of seven private universities. Data obtained from distributed questionnaires 149 and returned 130 respondend with Statistical Product and Service Solutions (SPSS). The results showed that entrepreneurial creativity had a positive and significant effect on entrepreneurial spirit and entrepreneurial mindset had a positive and significant effect on entrepreneurial spirit. This research can be developed by adding entrepreneurial education, innovation, and career choice variables. This research can be applied to undergraduate student in Indonesia that have management study programs.
\end{abstract}

Keywords: Entrepreneurial creativity, entrepreneurial mindset, entrepreneurial spirit, university students.

\section{Introduction}

The current era of globalization is driving a lot of competition. As competition increases, it is not matched with available job openings, which cause increasing educated unemployment [1]. Educated unemployment is increasing in number and is encouraging people to try to change their profession to become entrepreneurs [1]. Entrepreneurship has become something that is commonly heard today. Entrepreneurship is considered as the main pillar in improving a country's economy. An entrepreneurial profession that is getting smaller will result in a country difficult to compete in the global era [2]. Therefore, this

*Corresponding author : ranytaa@petra.ac.id 
profession is very important in a country. Currently, Indonesia has started to have many entrepreneurs but reported by the Sindo newspaper, Indonesian people who are entrepreneurs are only less than $4 \%$, and this number is lower than other neighboring countries such as Thailand, Malaysia, and Singapore [3].

In 2015, Indonesian with the Southeast Asian nations created the ASEAN Economic Community (AEC). This agreement is considered a good matter, because local Indonesian products can be easily recognized by other ASEAN countries, but can also bring negative impacts. For example, the creative industries of the other Southeast Asian countries also enter the Indonesian market and cause even more competition [4].This competition causes Indonesian business people who work as entrepreneurs to always improve and develop various ideas and product innovations from within the country in order to take advantage of this opportunity.

Becoming an entrepreneur must have the courage to face failure, but some people prefer comfort and do not want to face failure. Over time, many entrepreneurial professions appear. One of the things that increase entrepreneurial desire is the emergence of the phenomenon of downsizing. The phenomenon of downsizing or labor reduction by many companies has caused everyone to look for ways to survive including to create new businesses [5].

The number of young entrepreneurs in Indonesia is relatively few. Therefore the government continues to urge universities to conduct entrepreneurship training for students, for example, by providing education and entrepreneurship training so as to grow entrepreneurial spirit in each student [6]. Students are considered as the best moment in entrepreneurial training because they are more willing to face risks than adults and married couples [7]. The phenomenon of free trade, increasing work competition, increasingly limited job vacancies, and corporate have caused the importance of growing entrepreneurial spirit among university students in order to motivate them to become entrepreneurs.

The entrepreneurial spirit can emerge through one's observations in seeing opportunities that occur, seeing trends, seeing a problem, and so on. Higher Education is currently expected to be able to provide education and foster the entrepreneurial spirit among students. The students are expected to become young entrepreneurs who can help reduce unemployment. The entrepreneurial spirit can increase one's self-confidence, dare to take risks, and not give up easily [8]. Entrepreneurial spirit does not just happen right away but is driven by an entrepreneurial mindset [9] and entrepreneurial creativity [10].

Entrepreneurs usually have the mindset to continually look for and take every business opportunity even though life necessities have been fulfilled [11]. Students who have an entrepreneurial mindset can indirectly influence their actions in entrepreneurship. The entrepreneurial mindset is the mindset of a prospective entrepreneur and entrepreneur in utilizing uncertain conditions and uncertainty as opportunities to start a business [12]. Previous research of the influence of entrepreneurial mindset on entrepreneurial spirit in Indonesia is conducted by [9]. This study shows that the entrepreneurial mindset in Indonesia has begun to be seen as an influential matter or as a predictor that has contributed to the building of entrepreneurial spirit in Indonesia.

The ability to compete among countries can be in the form of trade competition for products or services offered. This competition requires someone who wants to be an entrepreneur to have the nature of entrepreneurial creativity. Entrepreneurial creativity means the ability of potential entrepreneurs to give customers new choices for products, services, or performance that are previously unimaginable or different [13]. Retnaningdiah, Sedjati, and Irawani prove the influence of creativity on entrepreneurial spirit [10]. This study shows that the innovation of craftsmen in the Bantul Regency, namely in Argosari village, have creativity and innovation that affect the entrepreneurial spirit of the craftmen themselves. 
Private universities in Indonesia have now begun to grow new entrepreneurs through students, including universities in Surabaya. Surabaya is a metropolitan city besides Jakarta and Medan in Indonesia. Therefore, the economic growth in this city is very rapid. Private universities in Surabaya are starting to realize the importance of an increasing number of entrepreneurs from the students. The curriculum of several private universities in Surabaya is now designed with entrepreneurship courses, and even several universities have provided business incubators to improve the students' entrepreneurial spirit. This research is seeking the influence of entrepreneurial creativity and entrepreneurial mindset to the entrepreneurial spirit of private university students in Surabaya.

\section{Literature review}

\subsection{Entrepreneurial creativity}

Creativity is defined as an aspect of thinking, as a collection of personalities, and as interactions in specific environments between thinking, personal traits, motivation, and feelings [14]. Creativity is a proposed new concept and idea, as this idea is created because they want to find alternatives by using their imagination [15]. Entrepreneurial creativity is an activity to bring innovative ideas and turn them into values that can create a business [16]. Entrepreneurial creativity is an entrepreneur's perspective on what must be done in two periods of time, namely today and tomorrow so that it can offer a more creative vision of the potential in the future [17]. Entrepreneurial creativity is an indispensable component in the entire entrepreneurial process, from generating ideas about new products and services to launching new businesses to gaining support, commercializing, and growing new businesses [13]. According to Chen, et al. the indicators of entrepreneurial creativity are the ability to create new and different business ideas, the ability to always look for new ways (out of the box), and the ability of prospective entrepreneurs in dealing with business problems [13].

\subsection{Entrepreneurial mindset}

According to McGrath and MacMillan the entrepreneurial mindset is the mindset of a prospective entrepreneur and entrepreneur in utilizing uncertain conditions, and this uncertainty can be used as an opportunity to do business [12]. The entrepreneurial mindset is a perception to create new ideas, look for and test opportunities and risks and will start and run a business [18].The entrepreneurial mindset is very closely related to the ability to think someone, where the actions and decisions of each person are different, and they try to utilize the resources they have to seize opportunities [19]. The entrepreneurial mindset is believed to help entrepreneurs from the wrong prejudice towards something, so they can identify and take advantage of opportunities that arise [20]. Davis, Hall, and Mayer argue that the entrepreneurial mindset is a collection of motivation, skills and thought processes that distinguish entrepreneurs and non-entrepreneurs; entrepreneurial mindset can also influence entrepreneurial success [21]. Indicators of entrepreneurial mindset according to Davis, Hall, and Mayer are independence, non-conformity, passion, and persistence [21].

\subsection{Entrepreneurial spirit}

The entrepreneurial spirit is within a person and will create confidence, the courage to take risks, oriented to the future, and not easily give up [8]. The entrepreneurial spirit is a desire and readiness for someone in running a business that is driven by several motivations. Individuals with entrepreneurial spirit have the desire to take advantage of opportunities by carrying out activities that create wealth and add value. The entrepreneurial spirit can be 
described not only in terms of personality characteristics but also in terms of motivational factors [22].

\subsection{Hypothesis development}

\subsubsection{The relationship between entrepreneurial creativity and entrepreneurial spirit}

Creativity can affect the variable of personal entrepreneurial spirit. This is proven by previous research by [10]. This study states that the entrepreneurial spirit of small businesses in the Bantul Regency, in Argosari village, is influenced by the creativity variable. Another research that shows the creativity influencing entrepreneurial spirit is carried out at Isfahan University. This study shows that the amount of risk, creativity, control, achievement, and autonomy have values that are more than the average value. This means that these dimensions affect the entrepreneurial spirit of graduate students at Isfahan University [23]. The most important cause of starting an entrepreneurial spirit is entrepreneurial education, creativity, and innovation [24]. Creativity for Timmons and Spinelli is the key to the concept of entrepreneurial spirit and is very relevant in educating entrepreneurship [25]. Based on the statements that have been mentioned, the following hypotheses can be concluded:

H1: It is suspected that entrepreneurial creativity influences the entrepreneurial spirit of private university students in Surabaya.

\subsubsection{The relationship between entrepreneurial mindset and entrepreneurial spirit}

Previous research states that the entrepreneurial mindset has a positive influence on entrepreneurial spirit variables in Indonesia by using simple random techniques on 59 respondents of higher education in Jakarta [9]. The entrepreneurial spirit will create confidence, the courage to take risks, oriented to the future, and not easily give up [8].Other research shows that the entrepreneurial mindset affects the entrepreneurial spirit of workers in Belgian companies. This research collects data through open and semi-structured interviews. The research states that corporate incubation is a way for companies to explore new ideas for their business innovation efforts, and also tools with the potential to instill entrepreneurial mindsets in company employees. Entrepreneurial mindset that is planted will increase entrepreneurial spirit to employees and ultimately will lead to increased company innovation ability [26]. Entrepreneurial mindset characteristics can be learned, including the ability to act on opportunities, learn from failures, and solve problems, as well as technical, business, interpersonal, and communication skills [27]. Based on the above statement, then concluded the following hypothesis:

$\mathrm{H} 2$ : It is assumed that the entrepreneurial mindset influences the entrepreneurial spirit of private university students in Surabaya

\section{Research method}

This research belongs to the quantitative research method. Quantitative research is research based on the philosophy of positivism. This research collects the data from samples of a population with a certain research instrument, analyzes the data with a statistical tool to test the hypothesis [28]. The population for this research is the undergraduate students from private universities in Surabaya, and the total sample is 130 respondents, based on the Slovin rule. To obtain the respondents, proportionate stratified random sampling is used as the size of the population contains some nonhomogeneous and proportionally stratified elements [28]. 
Hypothesis testing in this research follows the steps of SPSS, which come as:

(i). Validity and reliability tests

(ii). Classical assumption tests, which consist of normality test, multicollinearity test, and heteroscedasticity test.

(iii). Multiple regression analysis

(iv). Hypothesis test using t-test

(v). The t-test is used to examine the influence of each independent variable of entrepreneurial creativity (X1) and entrepreneurial mindset (X2) to a dependent variable of entrepreneurial spirit (Y).

\section{Data analysis and discussion}

Table 1. Validity test

\begin{tabular}{lllll}
\hline Variable & Indicator & rtest & rtable & Remark \\
\hline Entrepreneurial creativity & $\mathrm{X}_{1.1}$ & 0.567 & 0.1723 & Valid \\
& $\mathrm{X}_{1.2}$ & 0.634 & 0.1723 & Valid \\
& $\mathrm{X}_{1.3}$ & 0.645 & 0.1723 & Valid \\
& $\mathrm{X}_{1.4}$ & 0.712 & 0.1723 & Valid \\
& $\mathrm{X}_{1.5}$ & 0.566 & 0.1723 & Valid \\
& $\mathrm{X}_{1.6}$ & 0.603 & 0.1723 & Valid \\
Entrepreneurial mindset & $\mathrm{X}_{2.1}$ & 0.579 & 0.1723 & Valid \\
& $\mathrm{X}_{2.2}$ & 0.539 & 0.1723 & Valid \\
& $\mathrm{X}_{2.3}$ & 0.636 & 0.1723 & Valid \\
& $\mathrm{X}_{2.4}$ & 0.518 & 0.1723 & Valid \\
& $\mathrm{X}_{2.5}$ & 0.577 & 0.1723 & Valid \\
& $\mathrm{X}_{2.6}$ & 0.477 & 0.1723 & Valid \\
& $\mathrm{X}_{2.7}$ & 0.470 & 0.1723 & Valid \\
& $\mathrm{X}_{2.8}$ & 0.378 & 0.1723 & Valid \\
& $\mathrm{Y}_{1.1}$ & 0.499 & 0.1723 & Valid \\
& $\mathrm{Y}_{1.2}$ & 0.620 & 0.1723 & Valid \\
& $\mathrm{Y}_{1.3}$ & 0.511 & 0.1723 & Valid \\
& $\mathrm{Y}_{1.4}$ & 0.657 & 0.1723 & Valid \\
& $\mathrm{Y}_{1.5}$ & 0.570 & 0.1723 & Valid \\
& $\mathrm{Y}_{1.6}$ & 0.611 & 0.1723 & Valid \\
\hline
\end{tabular}

The validity test conducted in this study is aimed at all indicators with the values of $r$ test $\geq 0.03$, as shown in Table 1 ; therefore, all indicators are valid.

Table 2. Reliability test

\begin{tabular}{lccc}
\hline \multicolumn{1}{c}{ Variable } & Cronbach's Alpha & Alpha & Remark \\
\hline Entrepreneurial creativity & 0.681 & 0.6 & Reliable \\
Entrepreneurial mindset & 0.619 & 0.6 & Reliable \\
Entrepreneurial spirit & 0.602 & 0.6 & Reliable \\
\hline
\end{tabular}

The results of the reliability test can be observed in the table above, which shows the Cronbach's Alpha of the entrepreneurial prerequisite, entrepreneurial mindset, and entrepreneurial spirituality above 0.6 . Therefore, all variables are reliable.

Table 3. Normality test

\begin{tabular}{ll}
\hline & Result \\
\hline Number $(N)$ & 130 \\
Kolmogrov-SmirnovZ & 0.802 \\
Sig. & 0541 \\
\hline
\end{tabular}


The table above shows that the significance value is 0.541 , above 0.05 , so it can be concluded that the regression model consisting of the independent variables and the dependent variable is normally distributed.

Table 4. Multicollinearity test

\begin{tabular}{lcc}
\hline \multirow{2}{*}{ Variables } & \multicolumn{2}{c}{ Collinearity Statistics } \\
\cline { 2 - 3 } & Tolerance & VIF \\
\hline Entrepreneurial Creativity & 0.714 & 1.401 \\
Entrepreneurial Mindset & 0.714 & 1.401 \\
Dependent Variable & Entrepreneurial Spirit (Y) \\
\hline
\end{tabular}

The results of the multicollinearity test or the Variance Influence Factor Test (VIF test) can be observed from the VIF values of each independent variable which can be seen in Table 4, and the values are less than 10, with the tolerance value of each variable above 0.1 ; therefore, there is no multicollinearity in this study.

Table 5. Heteroscedasticity test

\begin{tabular}{lccc}
\hline \multicolumn{1}{c}{ Independent Variables } & B & t & Sig \\
\hline Constant & 1.121 & 5.548 & 0.000 \\
Entrepreneurial Creativity $\left(\mathrm{X}_{1}\right)$ & -0.017 & -0.362 & 0.718 \\
Entrepreneurial Mindset $\left(\mathrm{X}_{2}\right)$ & -0.187 & -3.459 & 0.385 \\
\hline
\end{tabular}

The table above shows that the significance is above 0.05 , meaning that there is no heteroscedasticity in the regression model.

Table 6. Multiple Regression Model

\begin{tabular}{lccc}
\hline \multicolumn{1}{c}{ Model } & Regression coefficient & t test & Sig \\
\hline Constant & 1.590 & 4.558 & 0.000 \\
Entrepreneurial Creativity $\left(\mathrm{X}_{1}\right)$ & 0.183 & 2.291 & 0.024 \\
Entrepreneurial Mindset $\left(\mathrm{X}_{2}\right)$ & 0.457 & 4.908 & 0.000 \\
$\mathrm{~F}_{\text {test } 28,986}$ & & & \\
\hline
\end{tabular}

Regression Model

$$
\mathrm{Y}=1.590+0.183 \mathrm{X}_{1}+0.457 \mathrm{X}_{2}
$$

The model can be interpreted as follows:

(i). The coefficient of entrepreneurial creativity $\left(\mathrm{X}_{1}\right)$ is 0.183 , indicating that the variable of entrepreneurial creativity has an influence on the entrepreneurial spirit variable.

(ii). The coefficient of the entrepreneurial mindset $\left(\mathrm{X}_{2}\right)$ is 0.457 , indicating that the variable of the entrepreneurial mindset has an influence on the entrepreneurial spirit variable.

Table 7. Correlation coefficient

\begin{tabular}{ccccc}
\hline Model & $\mathbf{R}$ & $\mathbf{R}^{\mathbf{2}}$ & Adjusted $^{\mathbf{2}}$ & Estimated standard error \\
\hline 1 & 0.561 & 0.315 & 0.304 & 0.361 \\
\hline
\end{tabular}

The value of $\mathrm{R}$ in Table 7. is 0.561 , meaning the relationship between the two independent variables with the dependent variable is quite strong and positive because the value of $R$ is approaching +1 . The adjusted $R^{2}$ value is 0.304 , meaning that the increase in entrepreneurial spirit is explained by the two independent variables by $30.4 \%$. The 
remaining $69.6 \%$ is explained by other variables outside these two existing independent variables.

Table 8. Model feasibility test

\begin{tabular}{lc}
\hline Dependent Variables (X) & Sig. \\
\hline Entrepreneurial Creativity & 0.000 \\
Entrepreneurial Mindset & 0.000 \\
\hline
\end{tabular}

The table above shows the value of Sig. in this regression model smaller than the significance level of 0.05 . This means that the regression model is feasible to explain the effect of entrepreneurial creativity and entrepreneurial mindset on entrepreneurial spirit variables.

Table 9. T-test

\begin{tabular}{llll}
\hline Independent Variables & $\mathbf{t}_{\text {table }}$ & $\mathbf{t}_{\text {test }}$ & Sig. \\
\hline Entrepreneurial Creativity & 1.978 & 2.291 & 0.024 \\
Entrepreneurial Mindset & 1.978 & 4.908 & 0.000 \\
\hline
\end{tabular}

The values of t-test for all variables show greater than the value of t-table, and the significance of all variables has the value below 0.05 , so it can be stated that the variables of entrepreneurial creativity $\left(\mathrm{X}_{1}\right)$ and entrepreneurial mindset $\left(\mathrm{X}_{2}\right)$ each have partial effects on the entrepreneurial spirit (Y).

\subsection{The influence of entrepreneurial creativity to entrepreneurial spirit on university students}

The results show that entrepreneurial creativity has an influence on the entrepreneurial spirit with the evidence of a t-test of 6.809, greater than the t-table of 1.976. This shows that entrepreneurial creativity is one of the influencing factors of the entrepreneurial spirit among private university students in Surabaya.

This research shows that the variable entrepreneurial creativity can affect a person's entrepreneurial spirit variable, with the evidence of the mean of 4.09 or average. This research is in accordance with a research by Chen, Chang, Wang and Chen, which state entrepreneurial creativity being an indispensable component in the entire entrepreneurial process, starting from generating new products and services ideas to launching new businesses, to gaining support, to commercialize and grow new businesses [13].

Other researchers also argue that entrepreneurial creativity is needed by every prospective entrepreneur in identifying and taking opportunities, competing with other entrepreneurs, and being able to maintain the competitive advantage of his business [16].Entrepreneurial creativity is able to encourage a prospective entrepreneur to have creative abilities to create new products and services to customers. Increasing products and services created over time will increase the entrepreneurial spirit of prospective entrepreneurs because they feel they have the desire and readiness to run a business and are not easily discouraged and have a strong motivation.

\subsection{The influence of entrepreneurial mindset to entrepreneurial spirit on university students}

The results show that the entrepreneurial mindset has an influence on the entrepreneurial spirit, with the evidence of the t-test of 3.198, greater than the t-table of 1.976. This shows that the entrepreneurial mindset is one of the factors that influence the entrepreneurial spirit of private university students in Surabaya. 
This research shows that the entrepreneurial mindset variable can affect a person's entrepreneurial spirit, as proven by the mean of 4.14 . This study is in accordance with research by McGrath and MacMillan saying that the entrepreneurial mindset is the mindset of prospective entrepreneurs in utilizing uncertain conditions, and uncertainty is used as business opportunities [12]. An entrepreneurial mindset can influence the entrepreneurial success [21] because an entrepreneurial mindset can improve the ability of prospective entrepreneurs to identify and take advantage of opportunities that arise [21]. Accuracy and carefulness to see new opportunities will increase the entrepreneurial spirit of the prospective entrepreneurs because they have the desire and readiness to open and running a business.

\section{Conclusion}

This research aims to examine the effect of entrepreneurial creativity and entrepreneurial mindset on the entrepreneurial spirit of private university students in Surabaya. The results of this study indicate that entrepreneurial creativity can influence the formation of entrepreneurial spirit in private university students in Surabaya. Likewise, the entrepreneurial mindset can influence the occurrence of entrepreneurial spirit in private university students in Surabaya. Students' entrepreneurial creativity needs to be improved in order to be able to generate unique business ideas. Higher education should stimulate entrepreneurial creativity by developing business competition and creating facilities to boost creativity. Students are expected to have a higher entrepreneurial mindset, as the students should not be afraid to be different from their friends to become entrepreneurs. Higher Education should open an entrepreneurial community. Through this community, the students can share insights and thoughts to form an entrepreneurial mindset that can answer business challenges. Students can learn from business practitioners in developing entrepreneurial insights.

\section{References}

1. M. Gewati. Kenapa lulusan perguruan tinggi makin susah mendapat pekerjaan? [Why are college graduates finding it harder and harder to find work?]. [Online] from https://edukasi.kompas.com/read/2016/04/23/17424071/Kenapa.Lulusan.Perguruan.Ti nggi.Makin.Susah.Mendapat.Pekerjaan.?page=all (2016). [Accessed on 25 October 2019] [In Bahasa Indonesia].

2. P.E. Wicaksono. Negara maju kembangkan tren baru entrepreneur economic. [Developed countries develop new economic entrepreneurial trends]. [Online] from https://www.liputan6.com/bisnis/read/630389/negara-maju-kembangkan-tren-baruentrepreneur-economic (2013). [Accessed on 5 September 2019] [In Bahasa Indonesia].

3. A. Chrisbiyanto. Generasi milenial didorong geluti wirausaha [Millennial generation is driven by entrepreneurship]. [Online] from https://ekbis.sindonews.com/read/1385080/34/generasi-milenial-didorong-gelutiwirausaha-1552052678 (2019) [Accessed on 1 September 2019]] [In Bahasa Indonesia].

4. A. Ika. Ini aneka investasi yang bisa dilirik di era MEA [These are various investments that can be glimpsed in the MEA era]. [Online] from https://money.kompas.com/read/2017/03/18/200000426/ini.aneka.investasi.yang.bisa. dilirik.di.era.mea?page $=$ all (2017) [Accessed on 10 October ] [In Bahasa Indonesia].

5. H.B.B Siswoyo. Jurnal Ekonomi Bisnis, 2:114-123(2009). [In Bahasa Indonesia]. http://fe.um.ac.id/wp-content/uploads/2009/10/bambang banu4.pdf 
6. P.A. Julianto. Perguruan tinggi harus lahirkan banyak wirausaha baru [Higher education must produce many new entrepreneurs]. [Online] from https://money.kompas.com/read/2017/04/05/190830426/perguruan.tinggi.harus.lahirk an.banyak.wirausaha.baru (2017) [Accessed on 6 October 2019] [In Bahasa Indonesia].

7. C.C. Amiranti. Bikin usaha sejak kuliah, apa perlunya? [Making an effort since college, what is the need?]. [Online] from

https://edukasi.kompas.com/read/2016/10/26/09555191/bikin.usaha.sejak.kuliah.apa.p erlunya.?page=all (2016) [Accessed on 20 October 2019] [In Bahasa Indonesia]

8. E.E. Pujiastuti. Peran penting jiwa kewirausahaan dalam mengembangkan usaha baru pasca bencana. [The important role of the entrepreneurial spirit in developing new businesses after a disaster]. Paper presented at Konferensi Nasional II: Media, Bisnis, dan Perdamaian FISIP UPN "Veteran" Yogyakarta, Indonesia (2013). p. 2344. [In Bahasa Indonesia]. http://repository.upnyk.ac.id/7901/

9. S.K. Rekha, S. Ramesh, S. Jaya-Barathi. International Journal of Entrepreneurship, 19,1:53-60(2015).

https://www.abacademies.org/articles/IJE_Vol_19_No1_2015.pdf\#page=58

10. D. Retnaningdiah, D.P. Sedjati, T. Irawani, Telaah bisnis, 16,1:47-58(2015) [In Bahasa Indonesia]. https://journal.stimykpn.ac.id/index.php/tb/article/viewFile/32/31

11. J.L. Thompson, Management Decision, 42,2:243-258(2004). https://www.emeraldinsight.com/doi/abs/10.1108/00251740410515861

12. R.G. McGrath, I. MacMillan, The Entrepreneurial Mindset. Boston, United States of America: Harvard Business School Press (2000).

https://books.google.co.id/books?id=we7-hg9YGbgC\&lr

13. M.H. Chen, Y.Y. Chang, H.Y. Wang, M.H. Chen, Entrepreneurship Research Journal, 7,3:1-15(2017). $\quad$ https://www.degruyter.com/view/j/erj.2017.7.issue-3/erj-20160001/erj-2016-0001.xml

14. A.J. Cropley, Definitions of creativity, In: Encyclopedia of Creativity, USA: Academic Press (2011), p. 358-368. https://www.doi.org/10.1016/B978-0-12-3750389.00066-2

15. C. Jackson, J. Morgan, C. Laws, International Journal of Event and Festival Management, 9,1:2-19(2018).

https://www.emeraldinsight.com/doi/abs/10.1108/IJEFM-10-2017-0062

16. K. Yogalakshmi, International Journal of Novel Research in Humanity and Social Sciences, 2,4:106-110(2015).

http://www.noveltyjournals.com/download.php?file=Entrepreneurial\%20Creativity $\% 2$ 0of\%20Rural\%20Entrepreneurs-305.pdf\&act=book

17. E. Carayannis, P. Harvard, A Minimalist Model for Measuring Entrepreneurial Creativity in Eco-Systems. In: Start-Up Creation The Smart Eco-Efficient Built Environment, UK: Woodhead Publishing (2016), p. 89-104 (2016). https://doi.org/10.1016/B978-0-08-100546-0.00006-6

18. E.L. Asenge, H.S. Diaka, A.S. Terna. International journal of Innovation, 6,2:123146(2018). https://dialnet.unirioja.es/servlet/articulo?codigo $=6726022$

19. C. Naumann. Entrepreneurial Business and Economic Review, 5,3:149-172(2017). https://www.ceeol.com/search/article-detail?id=569962

20. J.S. McMullen, A.S. Kier. Journal of Business Venturing, 31,6:663-686(2016). https://www.sciencedirect.com/science/article/pii/S0883902616301446

21. M.H. Davis, J.A. Hall, P.S Mayer. Consulting Psychology Journal: Practice and Research, 68,1:21-48(2016). https://psycnet.apa.org/journals/cpb/68/1/21/

22. S.H. Ang, D.G.P. Hong. Thunderbird International Business Review, 42,3:285-309 (2000). https://onlinelibrary.wiley.com/doi/abs/10.1002/15206874(200005/06)42:3\%3C285::AID-TIE2\%3E3.0.CO;2-5 
23. H. Aghajani, M. Abbasgholipour. Iranian Journal of Management Studies, 5,1:63-78 (2012). http://ijms.ut.ac.ir/article_24718_5.html

24. J.A. Timmons, S. Spinelli, New Venture Strategies: Entrepreneurship for The 21st century. Irwin: McGraw-Hill Publishers (2004). https://www.amazon.com/NewVenture-Creation-Entrepreneurship-Century/dp/0078029104

25. BPS Jawa Timur. Jumlah perguruan tinggi swasta di jawa timur menurut kabupaten/kota dan sejenisnya, 2016-2017 [Number of private universities in East Java by regency/city, 2016-2017]. [Online] from

https://jatim.bps.go.id/dynamictable/2017/10/10/122/jumlah-perguruan-tinggi-swastadi-jawa-timur-menurut-kabupaten-kota-dan-jenisnya-2016.html (2017).

26. J. Gonthier, G.M. Chirita, Journal of Innovation and Entrepreneurship, 8,8:121(2019). https://link.springer.com/article/10.1186/s13731-019-0104-0

27. T. Byers, T. Seelig, S. Sheppard, P. Weilerstein. Entrepreneurship: Its role in engineering education. The Bridge, 43,2:35-39(2013). http://epicenter.stanford.edu/documents/Bridge-Epicenter.pdf

28. Sugiyono. Metode Penelitian Kuantitatif Kualitataif dan Kombinasi (Mixed Methods). Bandung: Alfabeta (2016). https://books.google.co.id/books?id=0xmCnQAACAAJ 